\title{
Social Change and the Family: Comparative Perspectives from the West, China, and South Asia
}

\author{
Arland Thornton and Thomas E. Fricke \\ University of Michigan
}

\begin{abstract}
This paper examines the influence of social and economic change on family structure and relationships: How do such economic and social transformations as industrialization, urbanization, demographic change, the expansion of education, and the long-term growth of income influence the family? We take a comparative and historical approach, reviewing the experiences of three major sociocultural regions: the West, China, and South Asia. Many of the changes that have occurred in family life have been remarkably similar in the three settings-the separation of the workplace from the home, increased training of children in nonfamilial institutions, the development of living arrangements outside the family household, increased access of children to financial and other productive resources, and increased participation by children in the selection of a mate. While the similarities of family change in diverse cultural settings are striking, specific aspects of change have varied across settings because of significant pre-existing differences in family structure, residential patterns of marriage, autonomy of children, and the role of marriage within kinship systems."
\end{abstract}

This paper examines one of the central issues in the social sciences: how social and economic change influences family structure and relationships. More specifically, how do such social and economic trans-

\footnotetext{
- This paper has gone through a series of incarnations, originating as a paper presented at the Seminar on Social Change and Family Policies sponsored by the International Sociological Association Committee on Family Research, The Australian Institute of Family Studies, and the International Union of Family Organizations, Melbourne, Australia, August 19-24, 1984. The authors appreciate the comments of the organizing committee concerning an earlier draft. More recently, a draft of the paper was presented at the annual mecting of the Population Association of America in Chicago, April 30-May 2, 1987. Ronald Freedman, Orjan Hultaker, Stephen Mugford, Stella Quah, Susan Watkins, Sidney Goldstein, Keya Tucker, William Axinn, Susan Greenhalgh, Christopher Wilson, and anonymous journal referees also provided helpful comments on more recent drafts. Judy Baughn, Marge Dalian, Dawn Haavisto, and Donna Krips provided assistance in the preparation of the manuscript. While thanking everybody for their help, we assume all responsibility for errors of fact and interpretation.
}

(c) 1987 by the Eastern Sociological Society. All rights reserved. $0884-8971 / 87 / 0204-0746 \$ 1.50$ 
formations as industrialization, urbanization, demographic change, the expansion of education, and the long-term growth of income affect the family? These issues are important both for reasons of theory in the social sciences and because the policy goals of most countries are mediated through the central institution of the family. Additionally, much recent work on the demographic transition has stressed the need to account for the family organization's impact on fertility. Rapid social and economic change are important facts of life throughout much of the world; if the observations of several generations of social scientists are even remotely correct, these changes will have important implications for family life.

The influence of social and economic change on the family is one of the oldest issues in the social sciences. Several generations of social observers including anthropologists, demographers, economists, historians, and sociologists have been interested in family change and its causes and consequences. During recent decades there has been a flourish of historical research about Western families, and interesting and significant new research has been conducted outside the West.

In this paper we draw upon recent substantive findings from several disciplines to make some generalizations about the influence of social and economic change on family structure and relationships. We take a historical and comparative approach to this issue and examine the experiences of three major sociocultural regions: the West, China, and South Asia. ${ }^{1}$ A primary goal of this paper is to identify processes of social change that operate across regions as well as to specify ways in which family change depends upon cultural context. Our focus is on interrelationships between parents and children during the transition to adulthood. Specifically, we are interested in the involvement of children in the family economy, the living arrangements of young adults, marriage, and the autonomy of young people in making important decisions about their lives.

\section{FAMILY AND THE MODE OF SOCIAL ORGANIZATION}

There is general interdisciplinary agreement about the centrality of the family to social structure throughout the world. Yet the quest for

\footnotetext{
${ }^{1}$ By the West we mean the populations of Northwest Europe and the European migrants to North America and Australia. Our evidence from China comes primarily from Taiwan, although we occasionally refer to data from the mainland. By South Asia we refer to the area within the nation-states of Bangladesh, India, Nepal, and Pakistan. Also, where appropriate we refer to evidence from studies conducted in other geographical regions. Although we focus on similarities within regions, we understand the existence of considerable diversity within the three areas.
} 
a cross-culturally valid definition of this institution has been elusive, both because of the need to distinguish between the structures or forms of family and household units and the activities they perform and because of the range of variation in family composition and activity throughout the world (Murdock, 1949; Parsons, 1949; Bender, 1967; Yanagisako, 1979; Wilk and Netting, 1984; Levi-Strauss, 1984). Although we make no claim to having resolved the problem of definition, we provisionally define family as a social network, not necessarily localized, that is based on culturally recognized biological and marital relationships (cf. Netting, Wilk, and Arnould, 1984). The intensity and type of relationships among individuals within this network will vary with distance and specific kin status. Households are here defined entirely in terms of coresident individuals, whether kin or not.

For most of the people of the world, the basic principle of social organization has been family. Anthropologists, historians, and sociologists describing populations of the past consistently report that the fundamental activities of society, including production, distribution, consumption, reproduction, socialization, co-residence, and transmission of property, were primarily organized along kinship lines (Caldwell, 1982; Demos, 1970; Gallin, 1966; Ogburn and Nimkoff, 1955). Of course this is not to imply that in societies of the past the family was the only important institution or that there were no important forms of interaction or cooperation among unrelated individuals or groups. But this description does indicate that the basic organizational units conducting most of these activities were demarcated by kinship. ${ }^{2}$

The kinship groups conducting these activities generally pooled resources and responsibilities and participated in a specialization and division of labor among group members. These features required coordination among the activities and goals of individual family members and involved the integration of individual life courses with the life cycle of the family group as a whole. Kinship relations also served as vital linkages in binding individual family groups into larger communities. The stability of family systems from one generation to the next was maintained through complex relationships unifying production, distribution, consumption, reproduction, socialization, and transmission of property within and across kinship groups. Social control over younger household members was supported by control over these many diverse activities; stable life course and developmental trajectories were sup-

\footnotetext{
${ }^{2}$ We recognize the North American and European variants of this pattern. Although these organizational units included significant numbers of unrelated individuals or servants (Kussmaul, 1981; Macfarlane, 1979), family groups were central to organizing these activities. Also see Meillassoux (1981) for variants of this pattern in hunting and gathering societies.
} 
ported by expectations of the eventual assumption of the control of these activities by the younger generation.

The family mode of social organization is consistent with a wide range of economic environments. Sahlins (1972) identifies the "domestic mode of production" as a central feature of subsistence tribal economies, but his description is remarkably consistent with more recent work on agrarian production in which market considerations are important. Similarly, early forms of commodity production in a variety of settings involve high degrees of reliance on family organization even when agriculture recedes in importance (Medick, 1976).

While Sahlins (1972) and Caldwell (1976) have focused on domestic or family mode of production, our analysis of social change and the family is phrased in terms of mode of social organization; our difference in terminology is intended to grant the whole range of group activities the same analytical status as production (Ogburn and Nimkoff, 1955). A major theme of our analysis is the transformation of the family mode of organization by the proliferation of social structures outside the family that have come to perform or direct many of the activities formerly carried out by family units. The loci of many of the basic activities of society have been shifted to other social institutions with attendant modifications of family structure and relationships (Ogburn and Nimkoff, 1955).

Our perspective on family change is actor-based in the sense that we see such transformation as emanating from the behaviors of individuals and families in response to changing cultural and economic constraints and in pursuit of a hierarchy of goals. Activities commonly performed by households in familial modes of organization are increasingly performed by other groups, and we can eventually identify a very different mode of social organization. The resulting patterns of change are consistent with a model that focuses on increasing divergence in the strategies pursued by households and individual household members as they seek to perform necessary social activities.

Explanation of change in the family requires a description of essential characteristics of historical family patterns, the identification of the forces of change, and the delineation of how these forces affect specific aspects of social life. The goals of this paper are to identify social and economic forces that modify family structure and to specify certain processes whereby intergenerational rèlationships, the involvement of children in the family economy, entrance into marriage, and lateral relationships beyond the household are modified. Primary causal factors considered are shifts in the structure of production; the expansion of schools and education; increases in income; migration; and the uses of time. These aspects of change are singled out here because several studies have shown their importance, and data exist to enable investigation 
of their influence (Goode, 1970, 1982; Ogburn and Nimkoff, 1955; Shorter, 1975; Michael, Fuchs, and Scott, 1980). A more complete understanding would include an array of other forces such as mortality decline, the infusion of ideas and values from other cultures, political movements and governments with agendas around family issues, and the introduction of specific innovations such as radio, television, and contraception, but these will not be explicitly considered here.

\section{THE FAMILIAL MODE OF SOCIAL ORGANIZATION IN TAIWAN, SOUTH ASIA, AND THE WEST}

In this section we review the familial mode of social organization in the three settings. Our goals are to highlight common features of this mode in widely divergent cultural areas and to hint at the potential for variations within a basic organizational type. In addition, we use this review to establish baselines for discussing family responses to past and current developments in economies, educational institutions, and demographic patterns.

At one time or another the familial mode of organization has characterized all of the societies we consider here. Prior to the eighteenth century in the West and the twentieth century in Taiwan, the family was the primary organizational unit for many of the central activities of society (Cohen, 1970, 1976; Gallin, 1966; Greenhalgh, 1982, 1985; Demos, 1970; Laslett, 1965; Lesthaege, 1980; Ogburn and Nimkoff, 1955; Tilly and Scott, 1978). South Asia today encompasses a striking mix of social forms that include this mode of organization (Shah, 1974; Cain, 1977, 1978; Parry, 1979; Sharma, 1980; Fricke, 1986a). A typical feature of this familial mode of social organization in all three cultural settings is that the household organizes, directs, and manages its internal sources of labor to produce its means of existence. Although there is a strong association with agrarian settings, this kind of organization is not incompatible with urban and wage labor settings (Medick, 1976; Kertzer, 1984a, 1984b; Anderson, 1971; Laslett, 1965; Tilly and Scott, 1978). ${ }^{3}$ The important point here is that the majority of social activities are organized at the household level even where important productive resources are not owned at the houshold or family levels.

\footnotetext{
${ }^{3}$ Although we see our description of the family mode of social organization as generally correct, we also recognize the coexistence of alternative organizational forms such as agricultural wage-labor, patron-client relations, and plantation-production systems. Also, as Macfarlane (1986) and Wilson and Dyson (1987) note, there can be well-developed community-organized welfare mechanisms to redistribute resources to guarantee the wellbeing of families and individuals. Macfarlane (1986) also notes for England considerable monetary exchange in the economy.
} 


\section{Parallels}

An important element of this mode of social organization is senior generation control over the options of young family members. This control is maintained through greater access to the means of production in an environment of scarce economic alternatives. Furthermore, the requirements of production in this environment are such that members of most families must contribute to the household economy, with economic activities generally allocated along gender and age lines (although the exact allocation of tasks varies from one society to another). Children are involved in family production from an early age, and in many societies the contributions of older children to the household are substantial (Anderson, 1971; Tilly and Scott, 1978; Adepoju, 1977; Ware, 1977, 1978; Caldwell, 1982; Tienda, 1979; Macfarlane, 1976; Tan, 1983). In both China and the West the older generation maintained control over the household economy well into their children's adulthood (Berk * ner, 1972; Netting, 1981; Flandrin, 1979; Gallin, 1966; Taueber, 1970; Tang, 1978). Consequently the younger generation in both societies could not become truly economically independent before fathers transferred the economic unit to them or another independent unit could be formed. In South Asia, even where sons could demand their share of property at their discretion, the potential disruption of necessary family relationships that this might cause created strong pressures for them to leave control in the hands of the senior generation (Tambiah, 1973; Parry, 1979; Srinivas, 1976). Thus the independence of younger family mem bers tends to be limited in this mode of organization in all three settings (Katz and Davey, 1978; Kett, 1977; Modell, Furstenberg, and Hershberg, 1976; Tilly and Scott, 1978; Cohen, 1976; Gallin, 1966; Lewis, 1958; Fruzzetti, 1982; Cain, 1977, 1978).

This disparity in status, wealth, and power between parents and children makes the transfer of rights to the means of production an important process. For many children it marks the transition to independence and full adulthood, and for the parents it initiates the new stage of retirement. It is not surprising to find that this transition has been marked with tension and disagreement as different generations keyed their conflicting interests to the same economic unit. Berkner (1972) and Netting (1981) both mention such intergenerational tension among European peasants. Similar tension arises in South Asia, though family members often attribute it to conflict between the senior generation and a son's wife (Srinivas, 1976). The strongest pressure for the partition of economic units, however, occurs between brothers after the death of a father (Berreman, 1972; Parry, 1979; Davis, 1983). Similarly, in Taiwan, although the partition of households is often attributed to tensions among women, specifically between those who marry into the house- 
hold and their mothers-in-law, the real source of tension usually lies with the brothers (Cohen, 1976).

Education is primarily a function of socialization within the family in this type of social organization. Where institutional education coexists with the familial mode of organization (often in the form of religious institutions), there are often severe constraints on the extent to which it is open to all strata of society. Education thus becomes an explicit family strategy, often competing with and subordinate to the needs of family production. Consequently the educational attainments of children are limited-certainly by the standards of societies with well-developed school systems for large fractions of the population.

Disease and death have always had crucial implications for family life. In the past, many children died in infancy; many mothers died in childbirth; families with small children were often disrupted by the death of one of the parents; and many persons did not live to see their grandchildren (Uhlenberg, 1980; Sullivan, 1983). High mortality requires high fertility to ensure the replacement of children, and the conscious control of births was not widespread. Consequently, the number of children born to families was fairly large (Knodel, 1977; van de Walle and Knodel, 1980; Caldwell, 1977, 1982; Freedman, 1979; Chang, Freedman, and Sun, 1981; Coale and Zelnik, 1963). With high fertility balanced by high mortality, households, however, were generally not large.

\section{Cultural Variations}

Although the familial mode of social organization has characterized Western, Chinese, and South Asian societies at one time or another, the structure and composition of households and the forms of family organization have differed (Hajnal, 1982). The Western model has been primarily nuclear, with the typical household having only one married couple at any given time (Iaslett, 1965; Macfarlane, 1979; Shorter, 1975). While sometimes the Western household has included a single married couple and its parents, it has rarely included multiple couples of the same generation (Berkner, 1972; Laslett and Wall, 1972). In England young married couples often did not live in the same village as their parents (Macfarlane, 1986).

Unmarried children in the West often did not live with their own parents but resided in the homes of other families where they lived and worked as servants (Anderson, 1971; Tilly and Scott, 1978; McIntosh, 1984; Gillis, 1974; Laslett, 1965; Demos, 1970; Kussmaul, 1981; Hajnal, 1982 ). These arrangements, however, were often temporary, with transitions back to the natal family or to other families being quite common. Although the arrangements for servants varied, many received cash remuneration for their work in addition to lodging and food. Many of these 
servants tried to save at least some of the cash payments to help finance their marriages and the establishment of independent households (Hufton, 1981; Anderson, 1971; Macfarlane, 1986; Smith, 1981). ${ }^{4}$ Although these young people lived apart from their parents, their independence and autonomy were not complete since they resided and worked in households headed by others. Macfarlane provides evidence that in at least one seventeenth-century English setting, servants were considered family members (1970).

The Chinese family, at least ideally and often actually, included a young married son's parents and sometimes included multiple married brothers (Gallin, 1966; Cohen, 1976). The Western custom of children leaving their parental homes to live with others as servants was not typical of Chinese society, though many children were adopted permanently into other homes as family members (Taeuber, 1970; Wolf and Huang, 1980; Gallin, 1966). ${ }^{5}$

South Asian family forms vary dramatically among regions and castes (Kolenda, 1968; Shah, 1974), although the high caste model associated with Brahmans and Rajputs constitutes a prestigious ideal throughout the subcontinent (Minturn and Hitchcock, 1966; Srinivas, 1976; Eglar, 1960; Shah, 1974). This ideal includes households with vertically extended membership similar to that of China. Lateral extensions to include married brothers and their spouses could continue even beyond the lifetime of a father, but this seldom lasted long (Carter, 1984; Parry, 1979). A particular feature of the South Asian setting is that household groups are embedded within larger patrilineal kinship structures with lines of authority on some issues going beyond household boundaries. These authority relationships have been reported to be especially important in the activities of marriage, alienation of property beyond clan boundaries, and in maintaining powerful cultural notions of honor and moral behavior (Alavi, 1972; Tandon, 1968; Eglar, 1960; Parry, 1979; Fruzzetti, 1982). Cutting across these generally patrilineal modes of or-

\footnotetext{
"The practice of children living apart from their parents is also common in many African societies (Paige, 1986). It appears that a large majority of such children in Africa lived with other relatives (Caldwell, 1982; Ware, 1977), while living and working in the households of nonfamily members was very common in Western European populations.

${ }^{5}$ The number of societies with a way to move children from their parental to other households and the variety of ways to accomplish this demonstrate the importance of children to households and the significance of fertility variation for differences in recruiting family members. Knodel et al. report adoption in Thailand (1982), and others have reported it for South Asian societies in cases where a household cannot produce children of its own (Tambiah, 1973). A wife's lack of fecundity provides a culturally valid reason for taking a second wife in South Asia (cf. Stone, 1978). More systematic study of these reallocation processes and their interrelationship with other familial processes and structures is needed.
} 
ganization are larger variations in kinship organization and marriage structure, and these too have been shown to have implications for the relationships between families and the role of individuals within them (Dyson and Moore, 1983; Dumont, 1983; Yalman, 1971; Tambiah, 1973).

The nature of the dependence of young people has differed in these three settings. In Western societies, the nuclear nature of the family dictated that young people could not marry until they had the resources to create and sustain a new economic unit. Since a common way to obtain such resources was from one's father, and fathers were usually unwilling to give up control early in their own lives, marriage occurred fairly late (on average in the middle to late twenties). In addition, between a tenth and a quarter of Western populations did not marry at all (Greven, 1970; Hajnal, 1965; van de Walle and Knodel, 1980; Laslett, 1965; Uhlenberg, 1969). In China, on the other hand, the extended nature of the family allowed children to marry before they were economically independent. A similar pattern existed in South Asia. ${ }^{6}$ Consequently both the age at marriage and the percentage of people not marrying were substantially lower than in the West (Barclay et al., 1976; Casterline, 1980).

These differences in marriage behavior coincide with important differences in the role and meaning of marriage among these societies. Marriages in the West, for example, have long involved the wishes of the spouses themselves, and there were no necessarily special relationships between wider family groups implied by the marriages of their members (Macfarlane, 1970, 1986; Ozment, 1983). In South Asian society, on the other hand, the meaning of marriage was such that the important relationships engendered were at the level of wider family groups. Marriage not only reflected on the honor of whole families, it placed these families in particular relationships of cooperation and service to each other (Eglar, 1960; Fruzzetti, 1982; Fricke, Syed, and Smith, 1986; Dumont, 1983). Evidence for China suggests that marriage strategies were at least partially important as extensions of kin networks (Gallin, 1966; Cohen, 1976), and Watson (1985) reports that the extent to which marriage created networks of obligation among kin varied with class in much the same sense that the implications vary by caste in South Asia.

Relationships between parents and children were probably different among these three regions, too-at least partially because of differ-

\footnotetext{
${ }^{6}$ It is important to bear in mind that we are referring to a particular type of South Asian family pattern here. Some societies in the South Asian setting, in fact, are known for their relatively late ages at marriage (cf. Macfarlane, 1976; Fricke, 1986a). Interestingly, these same societies vary from high caste ideal family patterns in other important ways as well.
} 
ences in age at marriage, residential patterns of married couples, and residential and employment patterns of unmarried adults. Greater residential separation both before and after marriage and higher ages at marriage in the West than in China and South Asia probably provided Western children more opportunity for autonomy and required more self-reliance. This may have contributed to less control by Western parents over the mate selection process and over their children and children-in-law after marriage (Macfarlane, 1986). Further, this autonomy on the part of children seems to have had a relationship to the economic alternatives to parent-controlled means of production. Migrant European populations in North America may have had more opportunities for independence because of the greater availability of land to establish new economic units (Furstenberg, 1966; Lantz et al., 1968; Lantz, Schultz, and O'Hara, 1977).

\section{SOCIAL AND ECONOMIC CHANGE}

This outline of the family mode of social organization suggests that substantial changes outside and within the family are intricately related. Social transformation by industrialization, urbanization, educational expansion, demographic change, and monetization has altered the structure of family relationships in important ways. The following discussion examines some of these changes by focusing on intergenerational relations, mate selection, and marriage. Primary dimensions of social and economic change considered here include educational expansion, the growth of employment outside of the family, income growth, and urbanization. We focus on specific processes of family change associated with each of these factors, although we recognize that the joint occurrence of these transformations can produce family changes that go beyond additive effects of single factors.

\section{Education}

Virtually all societies have striven to develop Western-style education systems in response to the needs created by industrialization and urbanization (Tan, 1983). McDonald's analysis of World Fertility Survey data (1985) demonstrates that younger women obtained more education than older women in all of the thirty-four countries considered. Some of these increases were substantial, as in the case of Korea where 13 percent of ever-married women aged forty to forty-nine received post-primary education compared to 47 percent of those aged twentyfive to twenty-nine. Increases in Kenya and Venezuela across the same age groups were from 3 to 24 percent and 13 to 32 percent respec- 
tively. ${ }^{7}$ The expansion of schooling has been particularly rapid in Taiwan; whereas less than 15 percent of the women over age forty-five in 1984 had a junior high school education or more, over 90 percent of those aged fifteen to nineteen had obtained that level (Ministry of the Interior, 1985). In India, data on enrollment suggest far less change at secondary school levels although increases in female enrollment at primary levels have been dramatic. Female enrollment in grades one through four as a percentage of the population in corresponding age groups went from 20 percent to 97 percent from 1950 to 1975 . Corresponding percentages for enrollment in grades 9 through 11, however, went from less than 1 percent to 5 percent in the same period (Indian Council of Social Science Research, 1975).

School enrollment and educational attainment potentially influence the lives of individuals and their families in numerous ways (Schultz, 1973; Thornton, 1980; Caldwell, 1982). Most immediately, school enrollment can reduce the amount of time parents and other family members spend with young children. Instead of spending most of their maturing years with family members, children enter school at very young ages and spend large amounts of time outside of the family environment.

While increases in school enrollment are likely to decrease the amount of time young children spend with their families, the effect for older children depends upon the age at which children left home earlier. In Western societies, where older children often left their parental families to live and work elsewhere, increased schooling might delay the departure, as Katz and Davey (1978) report for Hamilton, Ontario, Canada. Thus in the West a probable result of expanded school enrollment is that older children lived with their parents longer, even though much of that time was spent in school. Nevertheless, the amount of time spent outside of family households-either their own families or those of others-would increase overall as school enrollment increased. For societies like China and South Asia, where children have lived with their parents until marriage, the effect of schooling increases has probably been similar for older and younger children: consistently less time spent with the family.

It is also important to consider which family members will find their contact with children diminished by schooling. In some South Asian settings, for example, educational increases for children may not have decreased time spent with fathers, because fathers may not have seen their young children during the day in any case because of their work

\footnotetext{
7 These comparisons are probably underestimates of the true increase in education over time because the comparisons were limited to ever-married women. Women who marry later in life tend to have higher levels of education, and more of these educated women are excluded from the younger cohort than from the older one.
} 
in the fields (Minturn and Hitchcock, 1966). Those members of the family whose impact on the socialization of children is reduced the most may be those outside of the nuclear family. This would be especially true in settings where families occupy more than one structure with shared childcare duties, as in the clan neighborhoods of some villages in South Asia (Kolenda, 1978; Kessinger, 1974).

School attendance is also likely to decrease children's availability to contribute to the family economy (Tan, 1983). Ethnographies document the conflicts between sending children to school and using them in productive family activities at early stages of educational expansion (Minturn and Hitchcock, 1966; Chekki, 1974). In addition, schooling substantially increases the direct costs of rearing children. These shifts may lead to lower fertility since the financial costs of having children increase and their economic value declines (Caldwell, 1976; Knodel, Havanon, and Pramualratana, 1983). The differential investment in children by sex has been particularly well documented in South Asia and Taiwan (Caldwell, Reddy, and Caldwell, 1982; Greenhalgh, 1985, forthcoming), and is a reflection of the differential usefulness of daughters in family economies, the earlier departure of daughters from their natal homes, and the patrilineal structure of society (Nag, White, and Peet, 1978; Greenhalgh, 1985).

School attendance results in shifting the locus of control and supervision from parents and family to a public institution during large portions of the day. Although the values and goals of school and family may overlap, they also probably diverge in important ways. School attendance also modifies relationships with peers by bringing together children whose families may not know each other well, thus providing a basis for new nonfamilial primary groups. In those instances where educational systems are coeducational, the pattern of interactions between the sexes has implications for mate selection.

Rapid increases in educational attainment create an educational generation gap. Children will have more access than their parents to ideas and skills valued beyond the local context-both directly through the schools and indirectly through literacy and access to the information network transcending their parents' more limited world (Ogburn and Nimkoff, 1955). The superior levels of education and access to new ideas among children can increase their ability and willingness to challenge parental authority while making parents less confident in enforcing their own wishes (Hull and Hull, 1977; Caldwell, 1982; Chekki, 1974).

Education enhances the opportunities of young adults in the new labor market and increases their potential wages. This may result in more autonomy from parents because children have more money of their own to spend or because their contribution to the household economy is increased. In Taiwan, for example, highly educated women were sub- 
stantially more likely to have worked in nonfamily enterprises and to have kept some of their earnings if they did work (Thornton, Chang, and Sun, 1984). However, at the same time that education increases the resources available for autonomy, the increased investment of parents in the educations of their children may also increase the subsequent obligations of children to return resources to their parents (Greenhalgh, 1985). This may be particularly important for daughters, whose obligations to repay parental investments are more specific and immediate than those of sons (Greenhalgh, 1985).

Finally, education provides young people with access to new ideas, both those of their own society's elites and those originating elsewhere. These messages can highlight the advantages of the Western nuclear family and its emphasis on individual freedom and autonomy (Caldwell, 1982), and even where these attributes are interpreted negatively, as in South Asian popular culture, they can have a significant impact. Other messages can come from governments that elevate allegiances to state and party above those allegiances to the family. Schools may significantly modify family dynamics by spreading these messages.

\section{Nonfamily Employment}

Before the onset of industrialization, the flourishing cottage industries of England involved young people and mothers in wage labor within their own homes (Levine, 1977). Large-scale industrialization strengthened a trend away from family employment with the creation or extension of a family wage economy in which people worked outside of their household boundaries (Anderson, 1971; Tilly and Scott, 1978). This new development occurred in the context of a largely agrarian society organized along family lines. The continuity with earlier forms of organization is evident in the extent to which many of the new business enterprises were controlled by family units and in the degree to which adults organized and directed younger family members within the work place (Anderson, 1971; Hareven, 1975, 1982; Tilly and Scott, 1978; Smelser, 1959; Greenhalgh, forthcoming; Medick, 1976). However, industrial production was increasingly separate from the family economy as people moved outside of direct family authority for wage work (Tilly and Scott, 1978; Levine, 1977).

Although systematic information about people's ideas and motivations during the early stages of Western industrialization is limited, it appears that both parents and children continued to view the economic activities of young people as family contributions. Initially these wage labor activities of children were responses to family needs rather than individual ones, and they were regarded as obligatory family contribu- 
tions (Early, 1982; Tilly and Scott, 1978; Hareven, 1982; Dublin, 1979). ${ }^{8}$ Current ethnographic work in China and South Asia suggests strong parallels in the tendency to send children to work for wages as a contribution to the family economy (Kung, 1983; Salaff, 1981; Greenhalgh, 1985; Parry, 1979; Chekki, 1974; Kessinger, 1974; Vatuk, 1972). The work of Caldwell, Reddy, and Caldwell on South India (1982, 1983) suggests that some of the motivation for educating sons may be to enhance their chances for acquiring bureaucratic positions with their attendant benefits for the family.

Once begun, the trend toward nonfamily employment has been rapid and dramatic, both in the West and among other populations. Vinovskis (1981) reports that by the middle of the nineteenth century substantial numbers of women in Massachusetts worked outside the home before marriage. McDonald (1985) has found in twenty-six of thirty-two populations where comparisons were possible using World Fertility Surveys that the percentages of ever-married women who had worked outside of agriculture before marriage was higher for women aged twentyfive to twenty-nine than for those forty to forty-nine. In some settings there have been striking increases in single women's wage labor participation. In Taiwan, for example, only about one-fourth of those women born during the 1930s and reaching adulthood right after World War II worked outside the home before marriage, compared to five-sixths of those born in the late 1950s (Thornton, Chang, and Sun, 1984). Similarly, the fraction who were employed outside of a family business or farm increased from one-fourth to four-fifths during the same period (Thornton, Chang, and Sun, 1984).

This separation of occupational and family roles has far-reaching effects in the lives of young people. As with school enrollment, nonfamily employment shifts the locus of primary activities out of the household. Such a change reduces the time young people spend in the family and increases interactions with peers in nonfamilial settings (Tilly and Scott, 1978). In Western societies, however, as employment was increasingly located outside the household, there was less need for young people to leave their parental family to work and live in the households of others (Kussmaul, 1981; Katz and Davey, 1978).

In many settings families can find nonfamily employment for their children within commuting distance of the household. This has been true of most urban families throughout the world, and in some societies, including the United States and Taiwan, there was extensive growth of

\footnotetext{
${ }^{8}$ In many cases the decision to employ children in the nonfamilial wage economy was made more by parents than by the children themselves. Ware (1977) reports this pattern for Africa, and fieldwork in Nepal by one of the present authors indicates a similar pattern.
} 
industrial employment in previously rural areas with consequences for the involvement of rural families (Vinovskis, 1981; Thornton, Chang, and Sun, 1984). With good transportation links, rural families living relatively close to cities could work there without changing residences (Lesthaege, 1977). In urban places, in rural places near cities, and in rural areas with industrial growth, the separation of workplace and household probably increased the proportion of children in the West who could and did live with their families. Katz and Davey (1978) re* port that among urban families in Hamilton, Ontario, the likelihood of children living with their own families increased during the early stages of industrialization. In Taiwan and South Asia, where most children traditionally lived with their own parents, nonfamily employment probably had little influence on residential patterns of children when there were employment opportunities near their homes.

The special circumstances of factory development in rural areas can also alter marital residence patterns. Klass (1978) reports such a change in patrilineal Bengal, where the opening of a bicycle factory in a rural area encouraged new husbands to move to their wives' villages when this brought them closer to the factory.

\section{Urbanization and Migration}

The special requirements of large-capital industry include largescale organization and worker concentration. Industrialization is often accompanied by urbanization, the establishment of new cities, and the expansion of old ones. The extent of urbanization may be restricted, however, as in Taiwan where good transportation and communication networks have facilitated conscious efforts at rural industrialization. Still, in most rural areas, including those of Taiwan, industrial employment usually requires geographic mobility, and rural outmigration to cities can be extensive (Greenhalgh, forthcoming). Some families move as entire units from agricultural areas of family production to urban areas and wage economies. In many cases, however, young people take jobs outside the family and migrate to urban areas while their parents maintain their original economic unit and residence (Anderson, 1971; Hareven, 1982; Hareven and Tilly, 1979; Tilly and Scott, 1978; Modell and Hareven, 1973).

These migrant young people often live with other relatives or, alternatively, with unrelated people as borders or lodgers. For instance, in the United States 15 to 20 percent of all nineteenth-century urban households included lodgers (Modell and Hareven, 1973). Another alternative was provided by companies that developed dormitories to house single workers during this early period of industrialization (Dublin, 1979; Hareven, 1982; Hufton, 1981; Hanlan, 1981; Tilly and Scott, 1978), a 
phenomenon that has been replicated in Taiwan and other societies (Kung, 1983; Thornton, Chang, and Sun, 1984). In Taiwan, about one-third of all women recently reaching adulthood have experienced living in a work-related dormitory (Thornton, Chang, and Sun, 1984). In the Kathmandu Valley of Nepal, one of the larger carpet factories in the valley provides quarters for small groups of young people from rural villages.

Work-related dormitory living represents a significant break from earlier living arrangements, and there was concern both in Taiwan and the United States that residents would not have the supervision they required. Efforts were made to ensure that dormitory living was as similar to familial arrangements as possible (Dublin, 1979; Hanlan, 1981; Kung, 1983), and supervisors were assigned to guide the behavior of the young residents and enforce rules concerning appropriate behavior. Although Kung (1983) reports that these mechanisms were able to restrict severely the independence of residents in the Taiwanese dormitories she studied, the number of supervisors was too small to allow complete supervision. It is likely that this made it ultimately impossible for dormitory supervisors to duplicate the control and knowledge of activities in the home environment. In the example from Kathmandu, some degree of knowledge is maintained through frequent visits to home villages, but the single-generation migrant residences nonetheless probably modify authority patterns. The option of using dormitories for single women has not been widespread in most of South Asia, where the roles of women are still quite restricted in rural areas. In these settings, a family would seriously undermine the marital options of their daughters by allowing them to leave their home villages unattended. It is clear that even in Taiwan and the United States dormitory living was a compromise between home supervision and the undesirable pattern of single people living alone (Kung, 1983; Hareven, 1982).

Some factors ameliorated the separation of young migrants and their families. Many moves from rural to urban areas were over a relatively short distance and permitted much visiting and return migration (Anderson, 1971; Hanlan, 1981; Ware, 1977; Alter, 1986; Goldstein, 1985), and in some cases migration was a family strategy in which multiple family and community members relocated in the same area (Anderson, 1971).

Experience in both Taiwan and South Asia demonstrates that migration and the separation of co-residence units for wage-labor reasons are often balanced by continuing economic interdependence and a kinship system stressing lateral extension beyond the household (Kessinger, 1974; Greenhalgh, 1985). The result is often a diversified and dispersed family economic unit (Greenhalgh, forthcoming). Punjabi children, for example, can spend much of their time in housebolds that are structurally nuclear when their father works at an urban occupation, but be- 
long to families that are joint and embody a shared economy. In these cases, children may alternate their residences among parental and other kin households. Thus, the impact of separating family members into separate households through migration to obtain urban jobs can be ameliorated by continuation of the integration of separate households with the family economy and family network (Kessinger, 1974).

During the twentieth century as living standards increased, as the population became more urbanized, and as rural-urban migration decreased, the phenomenon of boarding and lodging in the United States almost disappeared (Modell and Hareven, 1973). In recent years, however, single persons in the West have taken the initially discouraged step toward residential independence and are now increasingly maintaining their own private households (Kobrin, 1976; Michael, Fuchs, and Scott, 1980). Between 1950 and 1982 in the United States the percentage of never-married men aged twenty-five to thirty-four maintaining their own households increased from 10 to 43 percent, and an even larger increase occurred among women (Thornton and Freedman, 1983). This new pattern of independent living represents both a new stage in the life course and a new pattern of intergenerational relations. This trend has important implications for the amount and type of housing needed and the functioning of the housing market itself. It is too early to know if this innovation will also be adopted in the populations of Asia, Latin America, and Africa.

\section{Wage Income}

Although the long-term effect of wage income for children is diminished control by their parents, in the early stages of change parental control over the output of children remains strong. Hareven (1982) suggests that children contributing to their parents was an "unwritten law" in industrializing Manchester, New Hampshire. Dublin (1979) writes that payroll records from Lowell, Massachusetts, during the $1850 \mathrm{~s}$ and 1860 s even "provide repeated instances in which fathers signed for and probably picked up their children's pay envelopes. These children, then, did not even receive their wages which went directly into the family till." The evidence suggests that while many young people picked up their own pay checks, most contributed substantial portions of their earnings to the parents (Early, 1982; Tilly and Scott, 1978; Burton, 1985; U.S. Department of Labor, Women's Bureau, 1923). In many instances the children's contributions to their families had a significant impact on family living standards (Early, 1982; Dublin, 1979; Burton, 1985). Thus, it is possible that early industrial employment may have even increased older children's contribution to the family economy. 
Early paid employment sometimes represents a direct expansion of the "domestic economy" beyond the household as children earn money for diversifying family enterprise. In this case the meaning of work remains the same even as its organization changes. In South Asia, for instance, urban and rural segments of a family contribute to a single economic entity (Vatuk, 1972; Kessinger, 1974). Remittances have long been a part of the family economics of the Himalayan parts of South Asia (Parry, 1979; Berreman, 1972; Macfarlane, 1976). Such familial economic expansion during the initial period of industrialization has also been documented for Taiwan. A major theme of Kung's study of Taiwanese workers (1983) is the continuing obligation of single workers to contribute their incomes to their families, and a recent island-wide survey found that more than 70 percent of single employed women mostly gave their earnings to their parents (Thornton, Chang, and Sun, 1984). As in the West, these earnings of adult children often have a substantial impact on the standard of living of the entire family (Arrigo, 1980; Diamond, 1979; Greenhalgh, forthcoming; Salaff, 1981).

Children's control over their earnings has expanded steadily in the West (Tilly and Scott, 1978). Children living away from home probably began to keep larger fractions of their earnings, and today there is little expectation of children contributing substantially to the household when they are living with their parents (Bachman, 1983).

In Taiwan, parental control over children's earnings may also be slowly declining. The percentage of adult Taiwanese expecting to live with or be supported by their sons in old age has declined, and more people believe that children are less willing to support their parents in old age, to contribute wages to parents, and to take advice from parents (Coombs and Sun, 1981; Chang, 1987).

Although systematic data for the relationship between wage labor and children's autonomy does not exist for South Asia, ethnographic sources indicate that the outcome is related to the structure of the en tire family economy. Thus, partible inheritance systems together with a sense that a diversified family economy must include land bolster parental control even where some sons are engaging in wage work (Fricke, 1986a; Macfarlane, 1976; Parry, 1979; Shah, 1974; Srinivas, 1976; Tambiah, 1973; Vatuk 1972). Nevertheless, Caldwell, Reddy, and Caldwell (1982) note that parental authority is accommodated to nonfamilial work opportunities in South India, although declines in parental authority may have been greater for married than for unmarried children.

Under circumstances where parents are less able to observe, supervise, and control their children, it becomes easier for children to be influenced by others and to redefine their values and behavior in a nonfamilial context, which includes access to many ideas and influences 
unavailable in rural areas. ${ }^{9}$ Parents will adjust their behavior and authority to be consistent with the new economic relationships (see Goode, 1970,1982 ). But the freedom and autonomy associated with wage employment, urban living, and nonfamilial housing also have a reverse side: vulnerability. Children working away from the parental home are not also at least somewhat removed from parental protection (Tilly, Scott, and Cohen, 1980).

\section{MATE SELECTION AND MARRIAGE}

Because the changing structure of education, employment, and living arrangements of young people modifies their activities, their relationships to the economy, and their interactions with parents and peers, it would be surprising if these shifts had no influence on mate selection and marriage. As young people spend more time in school and in work outside of households, and as they establish their residences apart from parents, opportunities for interaction with the opposite sex increase while opportunities for parental supervision diminish (Kung, 1983; Hareven, 1982). One reflection of shifts is the decreased control of parents over the marriages of their children.

Because Western parents as compared to those in China and South Asia traditionally had less control over children's marital choices, the potential for decline in control was considerably less. Nevertheless, there is indirect evidence of declines in parental control over children's marriages in the United States and Europe, although many parents still maintain some ability to influence the process (Lantz, Schultz, and O'Hara, 1977; Smith, 1973; Tilly and Scott, 1978).

In Taiwan the pace of the decline in the control of parents over the choice of marital partners has been dramatic. The percentage of Taiwanese women reporting that their parents decided their marriage declined from over 75 percent for birth cohorts of the early 1930 s to just 15 percent for recent birth cohorts of married women, while the percentage saying that the decision was entirely theirs increased from 5 to 33 percent (Thornton, Chang, and Sun, 1984) ${ }^{10}$ McDonald (n.d.) reports similar trends in Indonesia and Caldwell, Reddy, and Caldwell

\footnotetext{
${ }^{9}$ The increased autonomy of young people in the West was also noted by contemporary observers, who often decried the change (Anderson, 1971; Hanlan, 1981). Ware (1977) notes, however, that in at least one African society wage employment implies little independence. Among the Mossi the control of the elders over the marriage market is so pervasive that there is little young people can do to gain independent adult status without parental approval.
} 
(1983) report that while parents continue to arrange marriages in South India, young people are consulted more now and have more to say in the choice of a mate. An examination of the determinants of the mate selection process in Taiwan also found that both education and employment outside the home were positively related to the participation of children in the mate selection process (Thornton, Chang, and Sun, 1984). Increased autonomy in the marriage process in South Asia has likewise been related to the availability of wage employment outside of the family (Caldwell, Reddy, and Caldwell, 1982, 1983).

Wolf and Huang (1980) report that the decline in parental control over marriage in Taiwan may have actually begun during the early decades of this century. Early in this century, marriages in Taiwan were often arranged very early in childhood with total parental control. In these marriages the future daughter-in-law was adopted into the home of the husband's family where she lived until marriage. But this pattern has disappeared today, and the change has been attributed to the increasing economic independence of young people, caused by a relatively small but still significant increase in employment opportunities outside the family context during the first few decades of the century (Wolf and Huang, 1980). Parish and Whyte (1978) also report disappearance of this marital pattern in Kwangtung Province of the People's Republic of China.

Throughout South Asia, marriage has been a pivotal institution with implications for a wide range of social processes including wealth transfers between patrilines, establishment of alliances, and the extension of social security networks based on kinship (Eglar, 1960; Dumont, 1983; Fruzzetti, 1982; Caplan, 1984; Lindenbaum, 1981; Parry, 1979; Yalman, 1971). Parental control over marriage and the relationship between families linked in marriage, have an impact on the ages at which daughters are married (Fricke, Syed, and Smith, 1986; Fricke, 1986b). Moreover, parental participation in most areas of South Asia has been universal until quite recently (Caldwell, Reddy, and Caldwell, 1982, 1983; Fricke, Syed, and Smith, 1986). ${ }^{11}$

Not surprisingly for an institution so central, changes in the marriage process have accompanied the wider transformation of society through educational and industrial expansion. Yet these changes in the

\footnotetext{
${ }^{10}$ Data collected by Parish and Whyte (1978) in Hong Kong from refugees from Kwang. tung Province in the People's Republic of China also suggest that the involvement of young people in marital choices has been increasing there; more recent data suggest the trend has been quite widespread in the country (Department of Population Statistics, 1985). "The exceptions have tended to be in areas geographically marginal to the core South Astan culture area, such as the Himalaya (cf. Acharya and Bennett, 1981; Fricke, 1986b).
} 
autonomy of marital decision-making, in most cases, benefit sons and sons-in-law more than daughters. Thus, Lindenbaum (1981) reports for Bangladesh and Caldwell, Reddy, and Caldwell (1982, 1983) report for South India that men are able to demand certain qualities in their brides and that arrangements are made with the active participation of future husbands, but that women have far less control over their options. Moreover, Caplan's (1984) work in urban South India sugests that the larger economic transformation's effect on family is still in terms of the relationships between broader kinship groups through marriage rather than in terms of increasing autonomy within the families themselves.

Extended schooling, which provides young people a new set of activities and roles, takes time and can lead to postponement of marriage. The potential for delay is much greater in societies like Taiwan where age at marriage was relatively younger than in Western societies where age at marriage was old enough to permit the attainment of high educational levels before marriage. The South Asian case, however, shows that the timing effects of education need not act alone in transforming the ages at which women marry. Evidence from rural Pakistan, for example, suggests that education combines with other culturally desirable characteristics for wives and daughters-in-law to offset the undesirability of marrying later. Thus, even those women who fail to complete a year of schooling marry signficantly later than women with no schooling at all (Fricke, Syed, and Smith, 1986).

The influence of paid employment outside the home on age at marriage probably depends upon the existing mate selection process, the existing pattern of age at marriage, and the control of parents over the earnings of their children. In the case where age at marriage was young and parents controlled mate selection and the earnings of their children, parents might want to postpone the marriages of their employed children so they could retain their earnings longer. This motivation might be particularly strong for parents of girls in societies where the married couple live with or near the husband's parents. For these families the arrangement of a marriage for a daughter with a high income is tantamount to a reduction in the standard of living for the family. Thus increases in the paid employment of unmarried women in this type of society would probably lead to an increased age at marriage.

Most of the populations of Asia in the past, including Taiwan's, fit this traditional pattern of early age at marriage and parental control over earnings and mate selection. Increased paid employment in these countries has been accompanied by significant increases in age at marriage and in many of these populations the increases have been rapid (Smith, 1980; Smith, Shadidullah, and Alcantara, 1983; McDonald, 1985; Hirschman, 1985; Coale, Anderson, and Harm, 1979). In Taiwan, for example, 
mean age at marriage for women increased from about eighteen in 1905 to nearly twenty-five in 1984, and is now higher than in the United States (Casterline, 1980; Ministry of the Interior, 1985). The relevance of employment shifts as well as lengthened education has been documented for several countries by studies showing that educated women, those living in urban areas, and those who work outside the family marry later than others (McCarthy, 1982; Thornton, Chang, and Sun, 1984; Hirschman, 1985). It should be noted, however, that continued expansion of the independence of children could result in parents no longer being able to control the earnings of their children or to influence greatly the marriages of their children, thereby reducing parental ability to postpone their children's marriages in order to retain the earnings of the children within the parental household.

Where marriage was historically contracted at older ages and children have extensive control over their earnings and the choice of a spouse, additional wage jobs and higher incomes could lead to earlier marriages (Levine, 1977). The wide discretion of children in this setting would allow them to translate more job opportunities and higher incomes into earlier marriages if that was desired. However, the preceding discussion shows no examples of societies that completely fit this description. While age at marriage was typically high in the West and parental control was generally less than in many Asian countries, parents still had influence over their children's earnings and mate selection. Thus, Western children who may have been motivated to use their wage income to marry and establish their own households may have been frustrated by parents who wanted them to continue to contribute to the parental household (see Verdon, 1979).

Important changes in marriage have been documented for Western societies before industrialization and urbanization, most notably in England in the eighteenth century (Wrigley, 1983; Wrigley and Schofield, 1981). However, in the century before World War II, there were only modest overall changes in age at marriage in the West, although there may have been important changes in some areas (Watkins, 1981; Levine, 1977). After World War II, however, there was a substantial marriage boom that lowered marital ages and increased the overall prevalence of marriage (Hajnal, 1953; Watkins, 1981). This increase in marriage may have been facilitated both by the increased income of young people and their increased ability to use their incomes to marry and establish their own households. More recently, however, marital ages and the proportion never marrying have risen (Carmichael, 1984; Roussel and Festy, 1979; Rodgers and Thornton, 1985).

This analysis suggests that the influence of social change on marriage age depends on parental authority over children. Children with 
more freedom to spend their earnings and more say in spouse selection probably have greater ability to translate expanded job opportunity into earlier marriage. Conversely, when parents have control over the marriages and earnings of their young adult children, increased earning power by those children can motivate parents to postpone their weddings.

The work of Caldwell and his colleagues in South India establishes the relevance of declining mortality to age at marriage in populations with a wide age difference between the sexes at marriage. In South India women historically married significantly younger than men. As mortality declined and the relative number of younger people increased, the number of women in their prime marrying years-relative to the number of such men-increased. The result was a significant marriage squeeze which put an upward pressure on age at marriage for women and decreased the value of women in the marriage market (Caldwell, Reddy, and Caldwell, 1983). Although Caldwell and his colleagues limit their observations to South India, this phenomena has likely occurred in other societies with similar marital patterns and improving mortality conditions.

The incidence of premarital sex and pregnancy is also modified by changes in the activities of young people, their interactions with their peers and parents, the mate selection process, and age at marriage. In much of South Asia, prestigious marriages used to be arranged between families before or shortly after daughters reach menarche. While postmenarcheal marriages theoretically increase the potential for premarital sex and pregnancy, other effective controls over female mobility minimize the risk. Similarly, in countries where the sexes are strictly segregated and spouses are chosen by their parents there is little potential for premarital sex; the scale of village society itself encourages widespread knowledge of individual behavior and facilitates social control. In societies that strictly controlled premarital sex, the potential for premarital sex and pregnancy increases as interaction between the sexes increases, children spend more time away from their parents, and children become more involved in the mate selection process. In recent years these changes have been accompanied by significant increases in the incidence of premarital sexuality and pregnancy in Taiwan (Thornton, Chang, and Sun, 1984), and increases in premarital pregnancy have been reported for Korea and the Chinese population of Malaysia (Rindfuss and Morgan, 1983). Shorter (1975) argues that premarital sex was relatively rare in traditional Western societies, but that its incidence increased in the early stages of industrialization.

In many Western populations, out-of-wedlock childbearing increased significantly during the eighteenth and early nineteenth centuries and then declined again during the late nineteenth and early twentieth centuries (Shorter, Knodel, and van de Walle, 1971). In the 
United States, the nonmarital fertility rate among teenage women increased steadily from 1940 through 1984 (National Center for Health Statistics, 1986). For older unmarried women, however, birth rates increased from 1940 through the middle 1960s and then declined until the middle 1970s when they began to increase again (Thornton and Freedman, 1983; National Center for Health Statistics, 1986). Similar but not identical trends have been reported for other English-speaking countries (Cutright and Smith, 1986). In Taiwan, the out-of-wedlock birth rate increased from 1906 to 1940 . While we are unaware of data for the 1940-1959 period, recent data suggest that the nonmarital childbearing rate in Taiwan declined significantly after 1960 (Barrett, 1980; Thornton, Lin, and Lee, 1987). Thornton and his colleagues (1987) argue that nonmarital childbearing declined in recent years in Taiwan despite increases in premarital sex and pregnancy because the increase in premarital sexual experience occurred primarily within the context of relationships that were close to marriage. Also, the linkage of trends in out-of-wedlock childbearing to trends in sexual experience among the unmarried is not easy because of the importance of other factors such as contraception and abortion in the determination of nonmarital fertility (Shorter, Knodel, and van de Walle, 1971; Cutright and Smith, 1986).

\section{SUMMARY AND CONCLUSIONS}

Many aspects of family structure and relationships, particularly as they intersect with the lives of children and young adults, have been modified throughout the world. This paper has shown how a number of these changes relate to the expansion of education, the development of a wage economy, the reduction of mortality, and other transformations in the larger social context. Processes and mechanisms whereby these forces could have had their influence on the family lives of young people have also been suggested.

Our point of departure throughout this paper is that the family has been a central institution in the performance of social activities in virtually all societies. We have identified those societies in which spheres of family and social activity have their most extensive overlap as having a family mode of social organization. The transformation of some of these activities in the wider society-through processes including monetization and paid employment, the displacement of socialization and education outside of families, migration, and urbanization-inevitably alter relationships within the family over individual life courses.

Many of the changes in family life have been remarkably similar in the three settings, especially in Taiwan and the West: the separation of the workplace from the home, increased training of children in nonfamilial institutions, the development of living arrangements outside the 
family household, increased access of children to financial and alternative productive resources, and more participation by children in the mate selection process. These similarities affirm the common dimensions of the impact of large-scale economic and social change on family structure and relationships.

While the similarities of family change in diverse cultural settings are striking, our review suggests that there is no single developmental sequence or pattern that all societies will experience. Specific aspects of change have varied across settings because of significant pre-existing differences in family structure, residential patterns of children, age at marriage, autonomy of children, and the role of marriage within ramifying systems of kinship and alliance. This essay makes the crucial point that changes within the family cannot be understood without considering the family's role in specific cultural and social contexts. Any consideration of family change must begin with a look at cultural definitions of family boundaries, the roles of family members, and the position of the family within the wider society. In addition to these structural differences in family and social organization, the processes of social and economic transformation themselves vary, producing differences in the trajectory of family change.

Our review of the evidence suggests the usefulness of viewing family change as an outcome of strategic behavior in which people follow the culturally constrained array of opportunities available to them. The family may use new opportunities within the social system to further and even strengthen preexisting goals, even as it mediates far-reaching economic transformations in society (Medick, 1976). In adapting to new circumstances, individuals and their families act in terms of the patterns of behavior and relationships already familiar to them (Kung, 1983; Hareven, 1982; Anderson, 1971). Existing patterns may also be "preadapted" to changing circumstances (Gusfield, 1967) and may even be instrumental in directing the course of economic change (Goode, 1970, 1982; Macfarlane, 1979; Thadani, 1978; Greenhalgh, forthcoming). In other instances, existing patterns may be modified as innovation occurs. Further, complexity is introduced by the time lags that beliefs, norms, and power relationships can cause (Ogburn and Nimkoff, 1955) and the differential rates of change in geographical and cultural subgroups.

Our conclusion about the processes of family change reinforces Goode's observation $(1970,1982)$ that explanations of family change should not rely on "grab bag" concepts such as industrialization and urbanization. Instead, careful attention needs to be devoted to specifying precisely causal mechanisms and processes.

This paper has shown how changing patterns of education, employment, and living arrangements influence family life. The effects of these changes, however, are not limited to those who become educated 
and work and live outside the family household, since the behavior and ideas of those who have these experiences can be observed and copied by young people not directly experiencing them. Similarly, in providing children more alternatives, increased schooling, paid employment, and nonfamilial living arrangements can alter the relationships between parents and children even if children do not participate directly in these institutions (Anderson, 1971; Caldwell, Reddy, and Caldwell, 1982). In addition, as new patterns of behavior become more available, norms and expectations can shift and influence the behavior and relationships of nearly everyone in the population. Consequently the spread of new family structure and behavior can proceed even more rapidly than the development of schools, the growth of nonfamilial employment and living arrangements, the expansion of cities, and the growth of income.

Although this essay has stressed the importance of structural shifts in education, employment, and residential patterns, these structural changes probably cannot account for all important trends in family structure and relationships that have occurred. Studies of Western families have shown the importance of ideological and religious trends (Lesthaege, 1977, 1980; Lesthaege and Wilson, 1986; Lockridge, 1983; Goode, 1970). Particularly important is the spread of secularization and the ideals of democracy and egalitarianism that could significantly modify family relationships.

Secularization may also be an important element of family change in Asia (Caldwell, Reddy, and Caldwell, 1982). In addition, the introduction of Western technology and economic organization in many societies currently undergoing rapid change has been accompanied or preceded by the spread of Western ideas and values. Indigenous nationalist movements can also foster independence among young people and modify intergenerational relations (Srinivas, 1976; McDonald, n.d.). As Thadani (1978) has argued, more theoretical and empirical research is needed to specify exactly how these new ideas and values influence family structure and relationships.

\section{REFERENCES}

Acharya, Meena and Lynn Bennett

1981 The Rural Women of Nepal: An Aggregate Analysis and Summary of Eight Village Studies. Kathmandu: Adepoju, A. Tribhuvan University Press.

1977 "Rationality and fertility in the traditional Yoruba society, South-West Nigeria." In J. C. Caldwell (ed.), The Persistence of High Fertility: 123152. Canberra: Australian National University.
Alavi, Hamza A.

1972 Kinship in West Punjab villages. Contributions to Indian Sociology $6(1): 1-27$.

Alter, George

1986 "Households and the life course: Natives and migrants in a nineteenth century Belgian city." Paper presented at the Population Association of America meetings, San Francisco, April 3-5.

Anderson, $M$. 
1971 Family Structure in Nineteenth Century Lancashire. London: Cambridge University Press.

Arrigo, L. G.

1980 "The industrial work force of young women in Taiwan." Bulletin of Concerned Asian Scholars 12:25-38.

Bachman, J. G.

1983 "Premature affluence: Do high school students earn too much?" Economic Outlook USA 10(3):64-67.

Barclay, G. W., A. J. Coale, M. A. Stoto, and $\mathrm{J}$. A. Trussell.

1976 "A reassessment of the demography of traditional rural China." Popula tion Index 42:606-635.

Barrett, R. E.

1980 "Short-term trends in bastardy in Taiwan." Journal of Family History 5(3):293-312.

Bender, D. $R$.

1967 "A refinement of the concept of household: Families, co-residence, and domestic functions." American Anthropologist 69:493-504.

Berkner, L. $\mathbf{K}$.

1972 "The stem family and the developmental cycle of the peasant household: An 18th-century Austrian example." American Historical Review $77: 398-418$

Berreman, Gerald D.

1972 Hindus of the Himalayas: Ethnography and Change. Berkeley: University of California Press.

\section{Burton, Orville Vernon}

1985 In My Father's House Are Many Mansions: Family and Community in Edgefield, South Carolina. Chapel Hill: University of North Carolina Press.

Cain, Mead

1977 "The economic activities of children in a village in Bangladesh." Population and Development Review $3(3) ; 201-227$.

1978 "The household life cycle and economic mobility in a village in Bangladesh." Population and Development Review 4(3):421-438.

Caldwell, J. C.
1976 "Toward a restatement of demographic transition theory." Population and Development Review 2(3,4):321-366.

1977 The Persistence of High Fertility. Canberra: Australian National University.

1982 Theory of Fertility Decline. New York: Academic Press.

Caldwell, J. C., P. H. Reddy, and

P. Caldwell

1982 "The causes of demographic change in rural South India: A micro approach." Population and Development Review 8:689-727.

1983 "The causes of marriage change in South India." Population Studies 37(3):343-361.

Caplan, Lionel

1984 "Bridegroom price in urban India: Class, caste, and 'dowry evil' arnong Christians in Madras." Man $19(3): 216-233$.

Carmichael, $G$.

1984 "The transition to marriage: Trends in age at first marriage and proportions marrying in Australia." Proceedings of Australian Family Research Conference, Vol. I, Family Formation, Structure, Values.

Carter, Anthony

1984 "Sex of offspring and fertility in South Asia: Demographic variance and decision procedures in 'joint family' households." Journal of Family History $9(3): 273-290$.

Casterline, J. B.

1980 "The determinants of rising female age at marriage: Taiwan, 19051976." Ph.D. dissertation, The University of Michigan.

\section{Chang, Ming-Cheng}

1987 "Changing familial network and social welfare in Taiwan." Paper pre sented at Conference on Economic Development and Social Welfare, Academia Sinica, Taipei, Taiwan, January 6-12.

Chang, Ming-Cheng, R. Freedman, and Te-Hsiung Sun

1981 "Trends in fertility, family size pref- 
erences and family planning practice: Taiwan, 1961-1980." Studies in Family Planning 12(5):211-228.

Chekki, Danesh A.

1974 Modernization and Kin Network. Leiden: E. J. Brill.

Coale, A. J. and M. Zelnik

1963 New Estimates of Fertility and Population in the United States. Princeton, NJ: Princeton University Press.

Coale, A. J., B. A. Anderson, and

E. Harm

1979 Human Fertility in Russia since the Nineteenth Century. Princeton, NJ: Princeton University Press.

Cohen, M. L.

1970 "Developmental process in the Chinese domestic group." In Maurice Freedman (ed.), Family and Kinship in Chinese Society: 21-36. Stanford: Stanford University Press.

1976 House United, House Divided: The Chinese Family in Taiwan. New York: Columbia University Press.

Coombs, Lolagene $C$. and

Te-Hsiung Sun

1981 "Familial values in a developing society: A decade of change in Taiwan." Social Forces 59:1229-1255.

Cutright, P. and H. L. Smith

1986 "Trends in illegitimacy among five English-speaking populations: 1940

Davis, Marvin 1980." Demography 23(4):563-578.

1983 Rank and Rivalry: The Politics of Inequality in Rural West Bengal. CamDemos, J. bridge: Cambridge University Press.

1970 A Little Commonwealth: Family Life in Plymouth Colony. New York: Oxford University Press.

Department of Population Statistics

1985 China In-Depth Fertility Survey (Phase I): Preliminary Report. Series CIDFS No. 3.

Diamond, $\mathrm{N}$.

1979 "Women and industry in Taiwan." Modern China 5:317-340.

Dublin, $\mathbf{T}$.

1979 Women at Work. New York: Colum- bia University Press.

\section{Dumont, Louis}

1983 "Hierarchy and marriage alliance in South Indian kinship." In L. Dumont (ed.), Affinity as a Value: Marriage Alliance in South India: 38-104. Chicago: University of Chicago Press.

\section{Dyson, Tim and Mick Moore}

1983 "On kinship structure, female autonomy, and demographic behavior in India." Population and Development Review 9:35-60.

Early, F. H.

1982 "The French-Canadian family economy and standard-of-living in Lowell, Massachusetts, 1870." Journal of Family History 7:180-199.

\section{Eglar, Zekiye}

1960 A Punjabi Village in Pakistan. New York: Columbia University Press.

\section{Flandrin, Jean-Louis}

1979 Families in Former Times: Kinship, Household, and Sexuality. Cam. bridge: Cambridge University Press.

\section{Freedman, Ronald}

1979 "Theories of fertility decline." Social Forces 58(1):1-17.

Fricke, Thomas E.

$1986 a$ Himalayan Households: Tamang Demography and Domestic Processes. Studies in Cultural Anthropology No. 11. Ann Arbor: UMI Research Press.

1986b "Marriage, household cycles, and the maintenance of equality among the Tamang of North Central Nepal." Paper presented at the 85th Annual Meeting of the American Anthropological Association, Philadelphia, December 3-7.

Fricke, Thomas E., Sabiha H. Syed, and Peter C. Smith

1986 "Rural Punjabi social organization and marriage timing strategies in Pakistan." Demography 23(4):489508.

Fruzzetti, Lina $M$.

1982 The Gift of a Virgin: Women, Marriage, and Ritual in a Bengali Society. New Brunswick, NJ: Rutgers University Press. 
Furstenberg, Frank F., Jr.

1966 "Industrialization and the American family: A look backward." American

Gallin, B. Sociological Review 31:326-337.

1966 Hsin Hsing, Taiwan: A Chinese Village in Change. Berkeley: University of California Press.

Gillis, J. R.

1974 Youth and History. New York: Academic Press.

Goldstein, Sidney

1985 "Forms of mobility and policy implications: A comparison of Thailand and China." Eighth Annual Amos H. Hawley Lecture, Population Studies Center, The University of Michigan.

Goode, W. J.

1970 World Revolution and Family Patterns. New York: The Free Press.

1982 The Family. Englewood Cliffs, NJ: Prentice-Hall.

Greenhalgh, $\mathbf{S}$.

1982 "Income units: The ethnographic alternative to standardization." Population and Development Review, 8 (supplement): $70-91$.

1985 "Sexual stratification in East Asia." Population and Development Review 11(2):265-314.

Forthcoming "Social causes and consequences of Taiwan's postwar economic development." In A. P. Wolf and $\mathrm{K}$. C. Chang (eds.), The Anthropology of Taiwan: Prehistory, Social History, and Modernization. StanGreven, P., Jr. ford, CA: Stanford University Press.

1970 Four Generations. Ithaca, NY: Cornell Univeristy Press.

Gusfield, J. R.

1967 "Tradition and modernity: Misplaced polarities in the study of social change." American Journal of Hajnal, J. Sociology 72(4):351-362.

1953 "The marriage boom." Population Index 19(2):80-103.

1965 "European marriage patterns in perspective." In D. V. Glass and D. E. C. Eversley (eds.), Population in His- tory: 101-146. Chicago: Aldine.

1982 "Two kinds of preindustrial household formation system." Population and Development Review 8:449494.

Hanlan, James $\mathbf{P}$.

1981 The Working Population of Manchester, New Hampshire: 18401886. Studies in American History and Culture No. 29. Ann Arbor: UMI Research Press.

Hareven, $T$. $K$.

1975 "Family time and industrial time: Family and work in a planned corporation town, 1900-1924." Journal of Urban History 1(3):365-389.

1982 Family Time and Industrial Time. New York: Cambridge University Press.

Hareven, T. and L. Tilly

1979 "Solitary women and family mediation in two textile cities: Manchester, New Hampshire and Roubaix, France. Unpublished paper.

\section{Hirschman, Charles}

1985 "Premarital socioeconomic roles and the timing of family formation: A comparative study of five Asian societies." Demography 22(1):35-59.

Hufton, Oliver $H$.

1981 "Women, work and marriage in eighteenth-century France." In R. B. Outwaite (ed.), Marriage and Society: 186-203. New York: St. Martin's Press.

Hull, T. H. and V. J. Hull

1977 "Indonesia." In J. C. Caldwell (ed.), The Persistence of High Fertility: 827-896. Canberra: Australian National University.

\section{Indian Council of Social Science}

Research

1975 Status of Women in India. New Delhi: Allied Private Publishers, Ltd.

Katz, M. B. and I. E. Davey

1978 "Youth and early industrialization in a Canadian city." In J. Demos and S. S. Boocock (eds.), Turning Points: Historical and Sociological Essays on the Family: S81-S119. Chicago: University of Chicago Press.

\section{Kertzer, David I.}


1984a "Anthropology and family history." Journal of Family History 9(3):201216.

1984b Family Life in Central Italy, 18801910: Sharecropping, Wage Labor, and Coresidence. New Brunswick, NJ: Rutgers University Press.

Kessinger, Tom G.

1974 Vilayatpur 1848-1968: Social and Economic Change in a North Indian Village. Berkeley: University of California Press.

Kett, J. F.

1977 Rites of Passage. New York: Basic Books.

Klass, Morton

1978 From Field to Factory: Community Structure and Industrialization in West Bengal. Philadelphia: Institute for the Study of Human Issues.

Knodel, $\mathbf{J}$.

1977 "Family limitation and the fertility transition: Evidence from the age patterns of fertility in Europe and Asia." Population Studies 31(2):219249.

Knodel, J., A. Chamratrithirong,

N. Chayovan, and N. Debavalya

1982 Fertility in Thailand: Trends, Differentials, and Proximate Determinants. Washington, DC: National Academy Press.

Knodel, J. A., N. Havanon, and

\section{A. Pramualratana}

1983 "A tale of two generations: A qualitative analysis of fertility transition in Thailand." Research Report No. 83-44 (October), Population StudKobrin, F. E. ies Center, University of Michigan.

1976 "The fall of household size and the rise of the primary individual in the United States." Demography 13(1):127-138.

\section{Kolenda, Pauline}

1968 "Religion, caste, and family structure: A comparative study of the Indian 'joint' family." In Milton Singer and Bernard S. Cohn (eds.), Structure and Change in Indian Society: 339-396. Chicago: Aldine.

1978 Caste in Contemporary India: Be- yond Organic Solidarity. Menlo Park, $\mathrm{CA}$ : Benjamin/Cummings.

\section{Kung, $\mathbf{L}$.}

1983 Factory Women in Taiwan. Studies in Cultural Anthropology No. 5. Ann Arbor, MI: UMI Research press.

\section{Kussmaul, Ann}

1981 Servants and Husbandry in Early Modern Europe. Cambridge: Cambridge University Press.

Lantz, H. R., R. Schmitt, M. Britton, and $E$. Snyder

1968 "Preindustrial patterns in the colonial family in America: A content analysis of colonial magazines." American Sociological Review 33:413-426.

Lantz, H., M. Schultz, and M. O'Hara

1977 "The changing American family from the preindustrial to the industrial period: A final report." American

Laslett, $P$. Sociological Review $42(3): 406-421$.

1965 The World We Have Lost. New York: Charles Scribner.

Laslett, $P$, and $R$. Wall

1972 Household and Family in Past Time. New York: Cambridge University Press.

Lesthaege, R. J.

1977 The Decline of Belgian Fertility, 1800-1970. Princeton, NJ: Princeton University Press.

1980 "On the social control of human re. production." Population and Development Review 6(4):527-548.

Lesthaege, R. J. and C. Wilson

1986 "Modes of production, secularization, and the pace of the fertility decline in Western Europe, 18701930." In A. J. Coale and S. C. Watkins (eds.), The Decline of Fertility in Europe: $261-292$. Princeton, NJ: Princeton University Press.

Levine, $D$.

1977 Family Formation in an Age of Na. scent Capitalism. New York: Academic Press.

Levi-Strauss, Claude

1984 "The family." In C. Levi-Strauss (ed.), The View from Afar: 39-62. New York: Basic Books. 
Lewis, Oscar

1958 Village Life in Northern India. Ur bana: University of Illinois Press.

Lindenbaum, Shirley

1981 "Implications for women of chang ing marriage transactions in Bangladesh." Studies in Family Planning $12(11): 394-401$.

Lockridge, K. A.

1983 The Fertility Transition in Sweden A Preliminary Look at Smaller Geographic Units, 1855-1890. Sweden: The Demographic Data Base.

Macfarlane, Alan

1970 The Family Life of Ralph Josselin Cambridge: Cambridge University Press.

1976 Resources and Population: A Study of the Gurungs of Nepal. Cambridge: Cambridge University Press.

1979 The Origins of English Individualism: The Family, Property, and Social Transition. Cambridge: Cambridge University Press.

1986 Marriage and Love in England: Modes of Reproduction $1300 \mathrm{~m} 1840$. London: Basil Blackwell.

McCarthy, J.

1982 "Differentials in age at first marriage." Comparative Studies 19:5-49.

\section{McDonald, Peter}

1985 "Social organization and nuptiality in developing societies." In J. Cleland and J. Hobcraft (eds.), Reproductive Change in Developing Countries: Insights from the World Fertility Survey: $87-114$. London: Oxford University Press.

n.d. "Changing courting behavior among Indonesian youth: National image versus local custom." Department of Demography, The Australian National University.

McIntosh, J. K.

1984 "Servants and the houschold unit in an Elizabethan English community." Journal of Family History $9(1): 3-23$.

Medick, Hans

1976 "The proto-industrial family economy." Social History 3:291-315.

Melllassoux, Claude
1981 Maidens, Meal, and Money: Capitalism and the Domestic Community. Cambridge: Cambridge University Press.

Michael, R. T., V. R. Fuchs, and

S. R. Scott

1980 "Changes in the propensity to live alone: 1950-1976," Demography 17:39-56.

Ministry of the Interior.

19851984 Taiwan-Fukien Demographic Fact Book. Taiped: Taiwan Republic of China.

Minturn, Leigh and John T. Hitchcock

1966 The Rajputs of Khalapur, India. New York: Wiley.

Modell, J. and T. K. Hareven

1973 "Urbanization and the malleable household: An cxamination of boarding and lodging in Ametican families." Journal of Marriage and the Family $35(3): 467-479$.

Modell, J., F. Furstenberg, and

T. Hershberg

1976 "Social change and transitions to adulthood in historical perspective." Journal of Family History 1(1):7-32.

Murdock, George P.

1949 Social Structure. New York: Macmillan.

Nag, Moni, Benjamin White, and

R. Creighton Peet

1978 "An anthropological approach to the study of the economic value of children in Java and Nepal." Current Anthropology 19(2):293-306.

\section{National Center for Health Statistics}

1986 Advance Report of Final Natality Statistics, 1984. U.S. Department of Health and Human Services Vol. 35, No. 4, Supplement.

\section{Netting, Robert M.}

1981 Balancing on an Alp: Ecological Change and Continuity in a Swiss Mountain Community. Cambridge: Cambridge University Press.

Netting, Robert M., Richard R. Wilk, and Eric J. Arnould

1984 "Introduction." In R. Netting, R. Wilk, and E. Arnould (eds.), Houscholds: 
Comparative and Historical Studies of the Domestic Group: xiti-xxxviii. Berkeley: University of California Press.

Ogburn, W. F. and M. F. Nimkoff

1955 Technology and the Changing Family. Boston: Houghton Mifflin.

\section{Ozment, Steven}

1983 When Fathers Ruled: Family Life in Reformation Europe. Cambridge, MA: Harvard University Press.

Paige, Hilary

1986 "Childbearing and childrearing: $\mathrm{Co}$ residence of mothers and children in tropical Africa." Paper presented at the Population Association of America meetings, San Francisco, April 3-5.

Parish, W. L. and M. K. Whyte

1978 Village and Family in Contemporary China. Chicago: The University of Chicago Press.

Parry, Jonathan P.

1979 Caste and Kinship in Kangra. London: Routledge and Kegan Paul.

Parsons, Talcott

1949 "The social structure of the family." In Ruth Nanda Anshen (ed.), The Family: Its Function and Destiny: 241-274. New York: Harper and Row.

Rindfuss, R. R. and S. P. Morgan

1983 "Marriage, sex, and the first birth interval: The quiet revolution in Asia." Population and Development Review 9(2):259-278.

Rodgers, W. L. and A. Thornton

1985 "Changing patterns of first marriage in the United States." Demography 22(2):265-279.

Roussel, L. and P. Festy

1979 Recent Trends in Attitudes and Behavior Affecting the Family in Council of Europe Member States. Population Studies, No. 4. Strasbourg: Council of Europe.

\section{Sahlins, Marshall}

1972 Stone Age Economics. New York: Aldine.

Salaff, J. W.

1981 Working Daughters of Hong Kong:
Filial Piety or Power in the Family? Cambridge: Cambridge University Press.

Schultz, T. W.

1973 "The value of children: An economic perspective." Journal of Political Economy 81:502-513.

Shah, A. M.

1974 The Household Dimension of the Family in India: A Field Study in a Gujarat Village and a Review of Other Studies. Berkeley: University of California Press.

\section{Sharma, Ursula}

1980 Women, Work, and Property in North-West India. London: Tavistock.

Shorter, E.

1975 The Making of the Modern Family. New York: Basic Books.

Shorter, E., J. Knodel, and

E. van de Walle

1971 "The decline of non-marital fertility in Europe, 1880-1940." Population Studies 25:375-393.

Smelser, N. J.

1959 Social Change in the Industrial Revolution: An Application of Theory to the British Cotton Industry. Chicago: The University of Chicago Press.

Smith, D. P.

1980 "Age at first marriage." Comparative Studies 7:1-18.

Smith, D. S.

1973 "Parental power and marriage patterns." Journal of Marriage and the Family 35:419-428.

Smith, P. C., M. Shadidullah, and

A. N. Alcantara

1983 "Cohort nuptiality in Asia and the Pacific: An Analysis of WFS surSmith, R. M. veys." Comparative Studies 22:7-34.

1981 "Fertility, economy, and household formation in England over three centuries." Population and Development Review 7(4):595-622.

Srinivas, M. N.

1976 The Remembered Village. Berkeley: University of California Press. 
Stone, Linda

1978 "Cultural repercussions of childless" ness and low fertility in Nepal." Contributions to Nepalese Studies $5(2): 7-36$

Sullivan, T. A.

1983 "Family morality and family mortality: Speculations on the demographic transition." In W. V. D'Antonio and J. Aldous (eds.), Families and Religions: Conflict and Change in Modern Society: 49-66. Beverly Hils, CA: Sage.

Taeuber, 1. B.

1970 "The families of Chinese farmers." In M. Freedman (ed), Family and Kinship in Chinese Society: $65-85$. Stanford, CA: Stanford University Press.

Tambiah, S. J.

1973 "Dowry and bridewealth and the property rights of women in South Asia." In J. Goody and S. J. Tambiah (eds.), Bridewealth and Dowry: 59169. Cambridge: Cambridge Lniversity Press.

Tan, J. $P$.

1983 "Schooling and demand for children: Historical perspectives." Education Department, The World Bank.

Tandon, Prakash

1968 Punjabi Century, 1857-1957. Berkeley: University of California Press.

Tang, Mei-Chun

1978 Urban Chinese Families. Taipei: National Taiwan University Press.

Thadani, V. N.

1978 "The logic of sentiment: The family and social change." Population and Development Review 4(3):457-499.

\section{Thornton, $A$.}

1980 "The influence of first generation fertility and economic status on sec. ond generation fertility." Population and Environment 3(1):51-72.

Thornton, A. and D. Freedman

1983 "The changing American family." Population Bulletin 38(4):3-43.

Thornton, A., Ming-Cheng Chang, and Te-Hsiung Sun

1984 "Social and economic change, inter" generational relationships, and family formation in Taiwan." Demog raphy 21(4):475-499.

Thornton, Arland, Hui-Sheng Lin, and Mei-Lin Lee

1987 "Social change, the family, and wellbeing." Paper presented at the Conference on Economic Development and Social Welfare, Academia Sin-

Tienda, $M$. ica, Taipei, Taiwan, January 6-12.

1979 "Economic activity of children in Peru: Labor force behavior in rural and urban contexts." Rural Sociology $44(2): 370-391$.

Tilly, L. A. and J. W. Scott

1978 Women, Work, and Family. New York: Holt, Rinehart and Winston.

Tilly, L. A., J. W. Scott, and M. Cohen

1980 "Women's work and European fertility patterns." In R. L. Rotberg and T. K. Robb (eds.), Marriage and Fertility: 219-248. Princeton, NJ: Princeton University Press.

\section{Uhlenberg, $P$.}

1969 "A study of cohort life cycles: Cohorts of native-born Massachusetts women, 1830-1920." Population Studies 23:407-420.

1980 "Death and the family." Journal of Family History 5(3):313-320.

\section{U.S. Department of Labor, Women's}

Bureau

1923 The Share of Wage-Earning Women in Family Support. Bulletin of the Women's Bureau, No. 30. Washington, DC: U.S. Government Printing Office.

van de Walle, E. and J. Knodel

1980 "Europe's fertility transition: New evidence and lessons for today's developing world." Population Bulletin $34(6): 3-43$

Vatuk, Sylvia

1972 Kinship and Urbanization: White Collar Migrants in North India. Berkeley: University of California Press.

Verdon, Michel

1979 "The stem family: Toward a general theory." The Journal of Interdisciplinary History 10(1):87-105. 
Vinovskis, M. A.

1981 Fertility in Massachusetts from the Revolution to the Civil War. New

Ware, $\mathrm{H}$. York: Academic Press.

1977 "Economic strategy and the number of children." In J. C. Caldwell (ed.), The Persistence of High Fertility: 469-590. Canberra: Australian National University.

1978 "The economic value of children in Asia and Africa: Comparative perspectives." Paper No. 50, East-West

Watkins, S. C. Population Institute, Honolulu, $\mathrm{HI}$.

1981 "Regional patterns of nuptiality in Europe, 1870-1960." Population Studies 35:199-215.

Watson, Rubie S.

1985 Inequality among Brothers: Class and Kinship in China. Cambridge: Cambridge University Press.

Wilk, Richard $R$, and

\section{Robert M. Netting}

1984 "Households: Changing forms and functions." In R. Netting, R. Wilk, and E. Arnould (eds.) Households: Comparative and Historical Studies of the Domestic Group: 1-28. Berkeley: University of California Press.

Wilson, Chris and Tim Dyson
1987 "Family systems and cultural change: Perspectives from past and present." Paper prepared for IUSSP Seminar on Changing Family Structures and Life Courses in LDCS, East-West Population Institute, Honolulu, Hawaii, January $5-7$.

Wolf, A. P. and Chieh-Shan Huang

1980 Marriage and Adoption in China, 1845-1945. Stanford, CA: Stanford University Press.

Wrigley, E. A.

1983 "The growth of population in eighteenth-century England: A conundrum resolved." Past and Present 98:121-150.

Wrigley, E. A. and R. S. Schofield

1981 The Population History of England 1541-1871: A Reconstruction. Cambridge, MA: Harvard University press.

Yalman, Nur

1971 Under the Bo Tree: Studies in Caste, Kinship, and Marriage in the Interior of Ceylon. Berkeley: University of California Press.

\section{Yanagisako, Sylvia Junko}

1979 "Family and household: The analysis of domestic groups." Annual Review of Anthropology 8:161-205. 